\title{
An Analysis of the Detrimental Effect of COVID-19 Pandemic: A Study in Bangladesh
}

\author{
Md. Rayhanul Islam , Shahed Ahamed Chowdhury ${ }^{2}$, Siddiqur Rahman ${ }^{3}$, Nurul Mohammad Zayed ${ }^{1, *}$ \\ ${ }^{1}$ Department of Real Estate, Daffodil International University, Bangladesh. \\ ${ }^{2}$ Barishal Metropolitan Police, Bangladesh. \\ ${ }^{3}$ Department of Business Administration, Daffodil International University, Bangladesh.
}

How to cite this paper: Md. Rayhanul Islam, Shahed Ahamed Chowdhury, Siddiqur Rahman, Nurul Mohammad Zayed. (2021) An Analysis of the Detrimental Effect of COVID-19 Pandemic: A Study in Bangladesh. Journal of Humanities, Arts and Social Science, 5(1), 116-124.

DOI: $10.26855 /$ jhass.2021.01.012

Received: February 28, 2021

Accepted: March 27, 2021

Published: April 28, 2021

*Corresponding author: Nurul Mohammad Zayed, Department of Real Estate, Daffodil International University, Bangladesh.

Email: zayed.bba@daffodilvarsity.edu.bd

\begin{abstract}
Across the world, 215 countries are affected by the COVID-19 pandemic including Bangladesh. The lockdown in the form of general holidays in Bangladesh has slowed down the economic activities which have affected the country's economy very adversely. This paper focused on analyzing the adverse effects of COVID-19 pandemic on some of the economic indicators as well as to make some recommendations that may help in formulating strategies for the policy makers. This descriptive study is based on secondary data from different local and international published sources. Many detrimental economic impacts of COVID-19 have been discussed in the paper including reduction in real GDP growth rate, reduced inflow of remittance till April 2020, adverse effect in tourism and aviation industry etc. The study also found some of the governmental initiatives appreciable. In the concluding part, the study proposed some guideline that may help in formulating policies to recover the COVID-19 situation.
\end{abstract}

\section{Keywords}

COVID-19, Lockdown, Real GDP Growth Rate, Policy Formulation

\section{Introduction}

At present, 215 countries is suffering from the COVID-19 pandemic (Worldometers, 2020). The exponential infection is forcing countries to endure lockdown. Bangladesh is the $10^{\text {th }}$ density populated country in the world. The country has limited healthcare facilities to serve its 16.4 million people. When COVID-19 outbreaks started government of Bangladesh had no other choice but to go for the great lockdown of 66 days in forms of general holidays. This scenario adversely affected country's economy and made it vulnerable considering fact only $15 \%$ of the country's population makes more than 6 USD per day (Saleh, 2020).

A sharp financial slump was projected in Bangladesh this year (World Bank, 12 April 2020). During January-March quarter of this financial year, all the major economic indicators were failing to meet expectations. Export and import enlisted negative growth, private sector credit development declined to 9.2\% (Khatun, 2020). At this point, Bangladesh detected first confirmed novel corona virus case on 08 March 2020. As of this composition, the quantity of affirmed cases in Bangladesh is 186,894, and the infection has taken 2,391 lives (Corona info, 14 July 2020). Enduring lockdown up to 30 May had an overwhelming impact on the national economy as well as on the household economy.

Because of this virus economy of Bangladesh is influenced by halting monetary activities, falling exchange, grater stress in banking part, disturbance of supply chain, declining private venture and so on. The day wedge earners were in dire need of income and food. 


\section{Literature Review}

From birth Bangladesh is struggling with disasters and humanitarian crisis. Bangladesh is a river delta situated at the bottom of Himalaya range and has a long history of conflict against impact of climate change. Other than that, at present nation has world biggest refugee camp. From birth Bangladesh has shown colossal versatility in battling off both natural and manmade disasters like Asian monetary emergency in 1997 and worldwide financial emergency in 2008 (The Daily Ittefaq, 2020). Because of the uncommon beneficiary of US-China trade war Bangladesh was treated to be one of the year's top performer in terms of development. However COVID-19 outbreak made the financial whiplash (Khatun, 2020).

Bangladesh is densely populated with constrained health care service. In national spending health sector got simply 4.9\% of total allocation (The Business Standard, April 15, 2020). With such a vulnerable health sector when Bangladesh was hit by COVID-19, the nation went for lockdown which had a crippling impact across the country. Until the emergency, economy of Bangladesh was growing at a rate of 7\% every year. A 5\% drop is anticipated by IMF and World Bank because of this pandemic. The effect is seen in three main avenues: first household monetary movement plunged after the shutdown; second is the declination of RMG exports which fell by $83 \%$; third is the tumble down in remittance (International Monetary Fund, 2020). The nation's economy became standstill and incapacitating impacts is observed in each sector (Global Times, 11 May 2020).

Demographic dividend is considered as a prime motivation to open work and commercial center in Bangladesh. The greater part of our populace is young who makes lion's share of workforce. It is frequently accepted shallow contention that they are less vulnerable against COVID-19. Young people are also vulnerable against COVID-19. In fact in Bangladesh, 72 \% of the affirmed cases are below 50 years (New Age, 13 April 2020). According to Michelle Murphy (2017), economization of life ascribe values on life subsequently serves the national economy. Here government component chooses which lives are "worth living" and "worth sparing". Consequently lives of less significant often become "disposable" to take care of thriving economy. In this manner one vital inquiry of "who to live and who to bite the dust" remains quiet (Daily Star, 10 May 2020).

Pioneers over the world are occupied with damage control and planning for comforting upcoming financial emergency. It is obvious that budgetary organization and banking division around the world will confront remarkable instability in the forthcoming months. The actual ramification on the economy of Bangladesh will depend on the duration of COVID-19 emergency (Light Castle Analytical Wing, 9 May 2020).

\section{Objectives of the Study}

The study primarily intends to investigate and analyze the likely impact of COVID-19 pandemic on some of the major economical indicators of Bangladesh. It also intends to propose some administrative guidelines that might help in formulating policies to tackle the challenges arising due to the COVID-19 pandemic. Additionally, further research scopes are expected to be created from this study.

\section{Methodology}

This is an explanatory and descriptive paper based on data from different secondary sources. Both qualitative and quantitative approaches were adopted in collecting and analyzing data. Data were collected from secondary source. In conducting this desk research, data published by different national and international organizations like IMF, Bangladesh Bank were used. Various statistical tables are used to display the necessary data that are analyzed. Moreover, relevant national and international literatures have been reviewed in conducting the study that has increased the validity of the research.

\section{Critical Analysis}

The economy of Bangladesh is confronting recession for incredible lockdown caused by COVID-19 Pandemic. The following Charts and Tables will help us to understand the actual impact of COVID-19 on national economy briefly but my focus will be on RMG Sector of Bangladesh.

\subsection{Forthcoming Economic Derailment}

General Holiday from 26 March, 2020-30 May 2020 was declared by administration to curb spread of COVID-19 which was a shock for formal and informal sectors. According to IMF projected real GDP of Bangladesh is to decelerate to 2\% in FY 2019-20 (Figure 1). 


\section{Real GDP Growth}

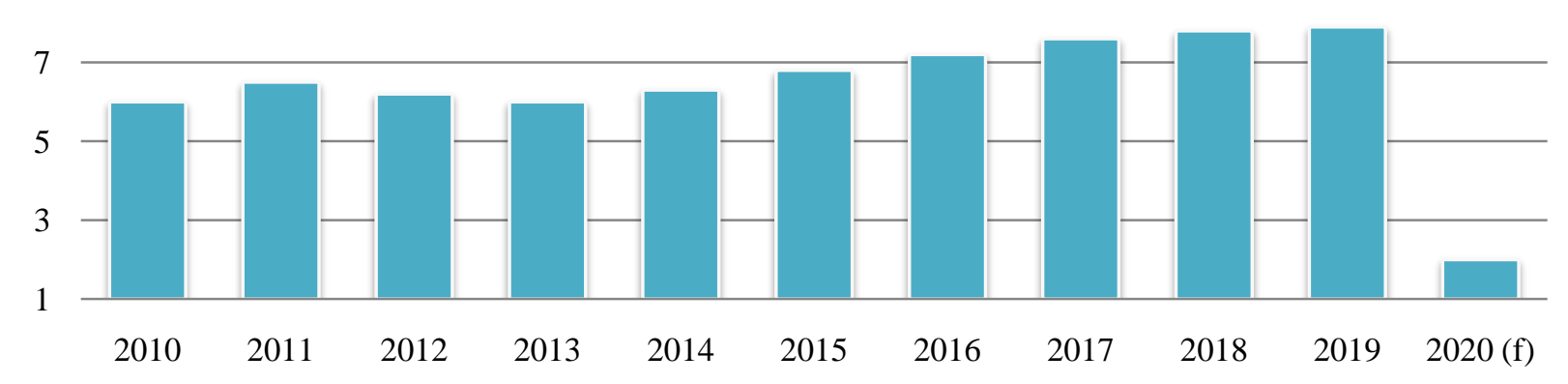

Figure 1. Real GDP Growth Percentage. Source: International Monetary Fund.

\subsection{Waning Stock Market}

From January, Bangladeshi Stock market had a descending pattern. But after the Pandemic, it has witnessed huge fall and selloff. In January-March quarter, DSEX of Dhaka Stock Exchange plunged 849 Points which is most depressing first quarter in its history (Figure 2).

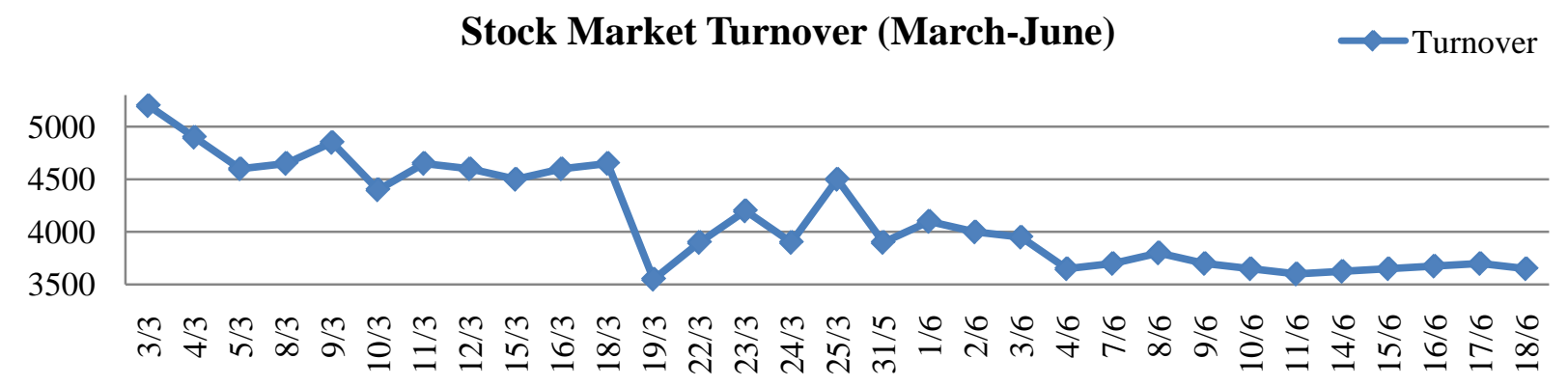

Figure 2. The stock market turnover (March-June). Source: BRAC EPL Stock Brokerage Ltd.

\subsection{Declining Remittance Inflows}

Due to pandemic, Gulf and Western nations were forced to financial shutdown and the impending economic recession places the wage earners in perilous situation. Many migrants have lost their job and its indicating a descending pattern in remittance inflows in the first quarter (Figure 3).

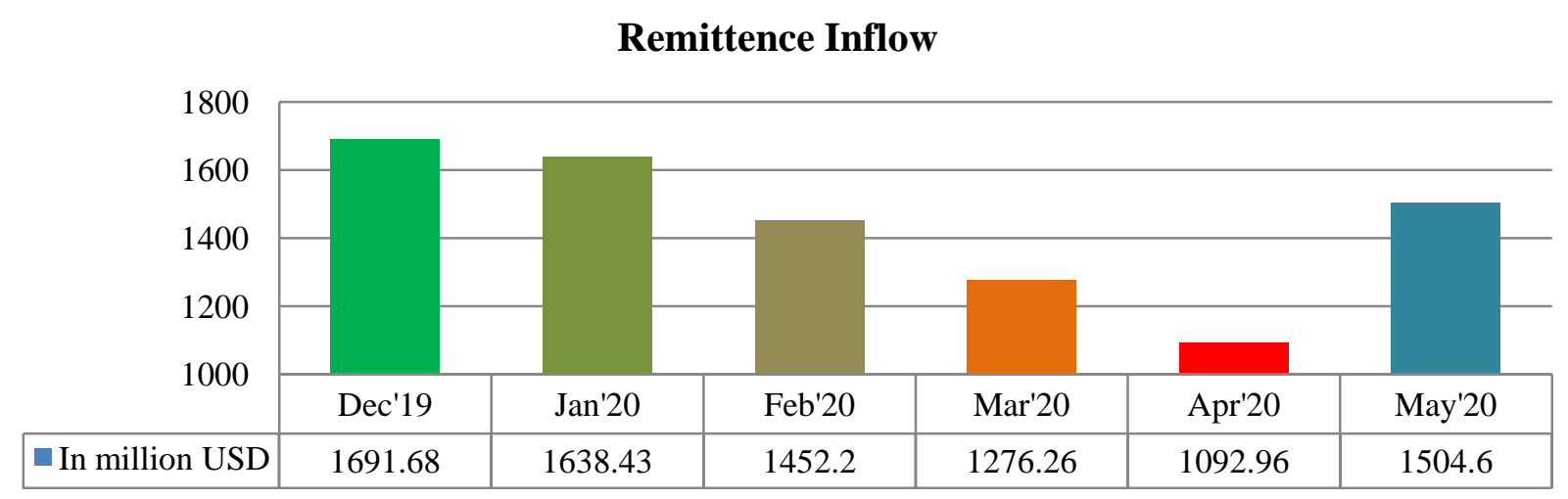

Figure 3. Remittance inflows. Source: Author compilation from Bangladesh Bank. 


\subsection{Rural Economy Dwindles}

A drastic price drop is observed in fisheries, dairy, Poultry due to decreased demand in respective sectors (Figure 5). Due to lockdown, a large number of people with no income moved to the village which pushed the rural economy at a vulnerable stance.

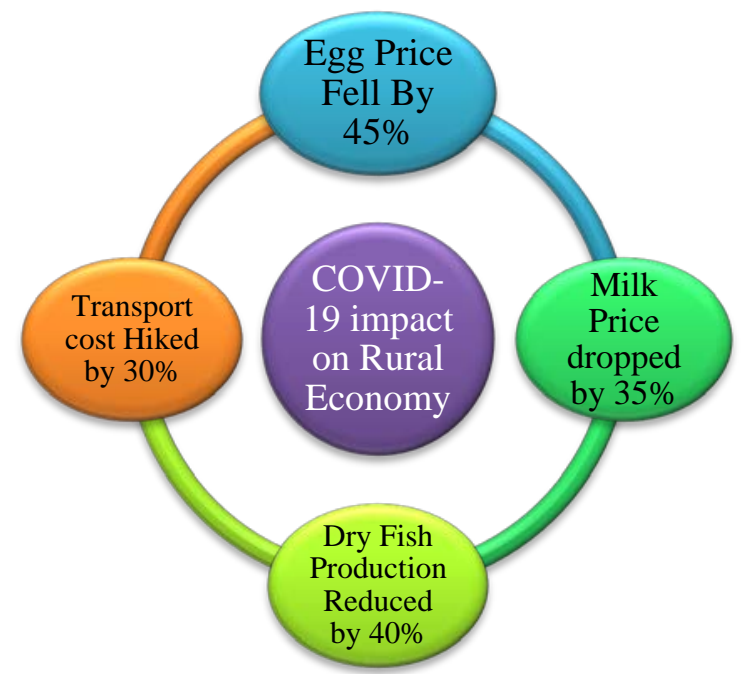

Figure 4. COVID-19 impact on rural economy. Source: The Business Standard.

\subsection{Decelerating Credit Growth of Private Sector}

With the recent directives on interest rates on deposits and loans of $6 \%$ and $9 \%$, disruption of Supply Chain in different parts of the Country and exacerbated credit demand by private Sector made situation worse. Bangladesh Bank Data also represent that credit growth of private sector is declining after the outbreak (Figure 5).

\section{Declining Private Sector Credit Growth}

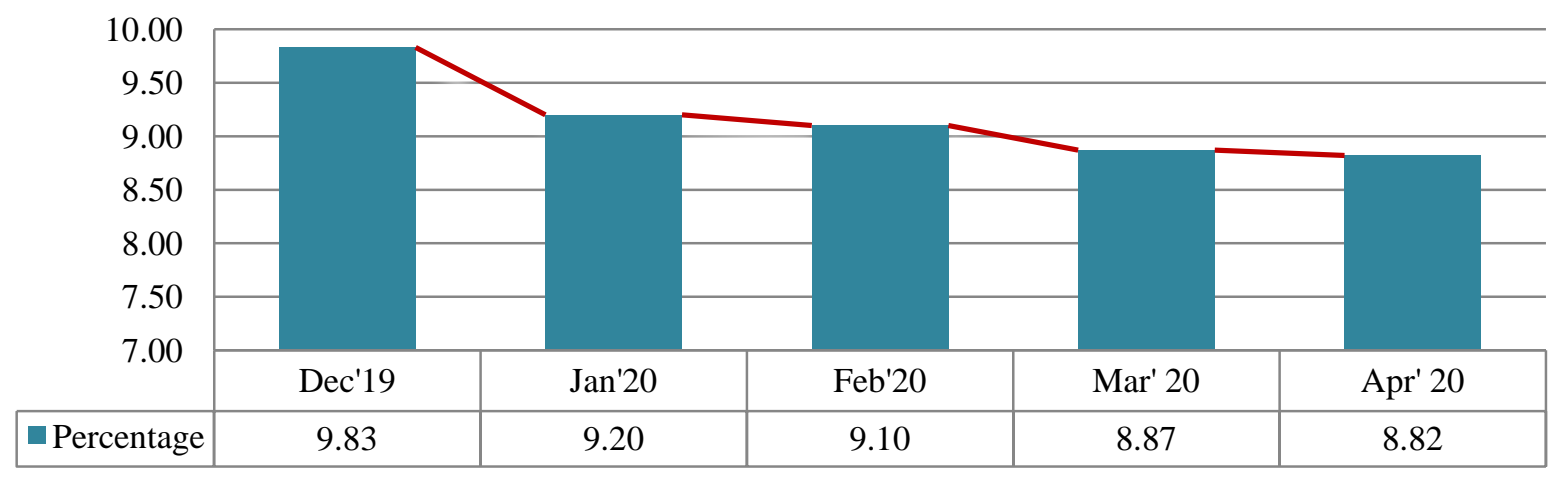

Figure 5. Declining Private Sector Credit Growth. Source: Bangladesh Bank.

\subsection{Adversely Affected Aviation Industry}

In Flight numbers drastically dropped after COVID-19 outbreak. The Local Bangladeshi airlines incurred a combined loss of 3.5 billion after the pandemic. Biman Bangladesh airlines cancelled $70 \%$ of its international flight and domestic flight fell to 15\%-20\% (Figure 6).

\subsection{Dilemma in Tourism and Hospitality}

A loss of BDT 57 Billion is projected by Tour operator association of Bangladesh and jobs of around 40 million people is at risk who are directly or indirectly involved with this sector. Occupancy rate of luxury hotels declined due to travel restriction and flight cancellation (Figure 7). 


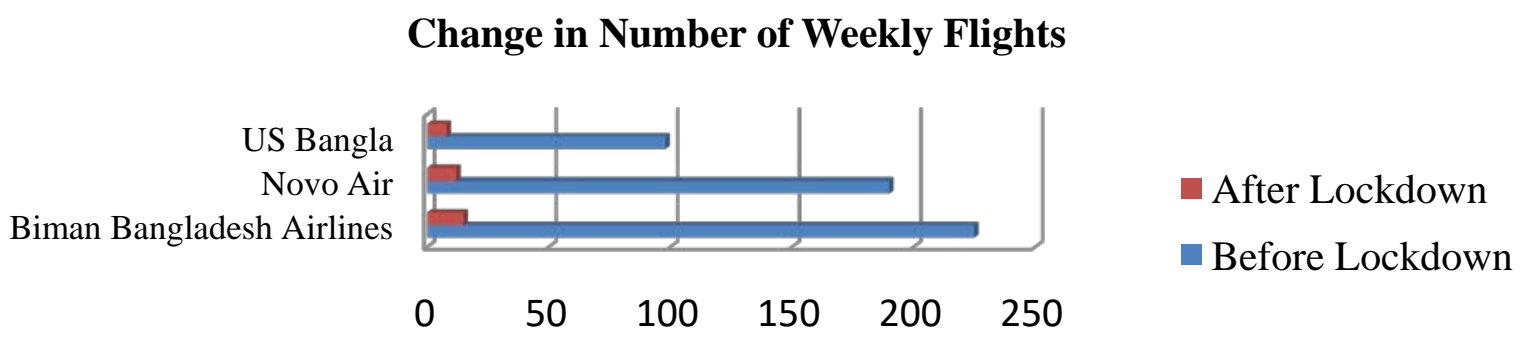

Figure 6. COVID-19 impact on weekly flight numbers. Source: The Daily Star.

\section{Changes in Occupency Rate in Luxary Hotels due to Lockdown}

Pan Pacific Sonargaon

Amari Dhaka

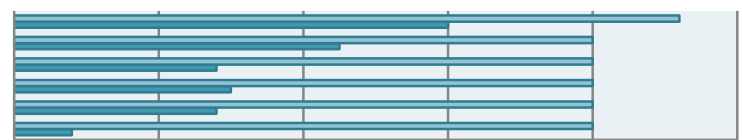

$\begin{array}{llllll}0 & 20 & 40 & 60 & 80 & 100\end{array}$
Before Lockdown

After Lockdown

Figure 7. COVID-19 impact on the occupancy rate of luxury hotels. Source: The Daily Star.

\subsection{RMG Sector}

The readymade Garments (RMG) industry, which has been vital in the monetary development of Bangladesh, is confronting a dubious future after the COVID-19 pandemic (Figure 8). The business, which is the world's second biggest exporter of readymade clothing, is currently staring at loss of $\$ 6$ billion.

\section{Impact of COVID-19 On Bangladesh RMG Industry}
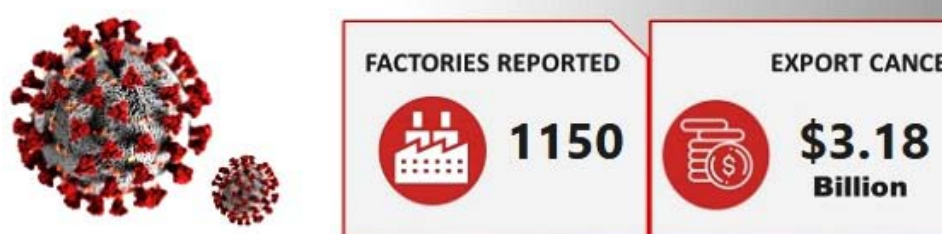
WORKERS AFFECTED
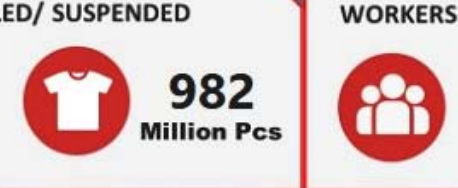

Figure 8. Impact of COVID-19 on Bangladesh RMG industry. Source: BGMEA.

In Bangladesh, a huge number of the individuals live hand to mouth and income sharing is not equal. After the pandemic, Bangladesh has lost work order of nearly 3 billion USD. Export of Knit Product (Figure 9) and Total Export (Figure 10) reduced dramatically.

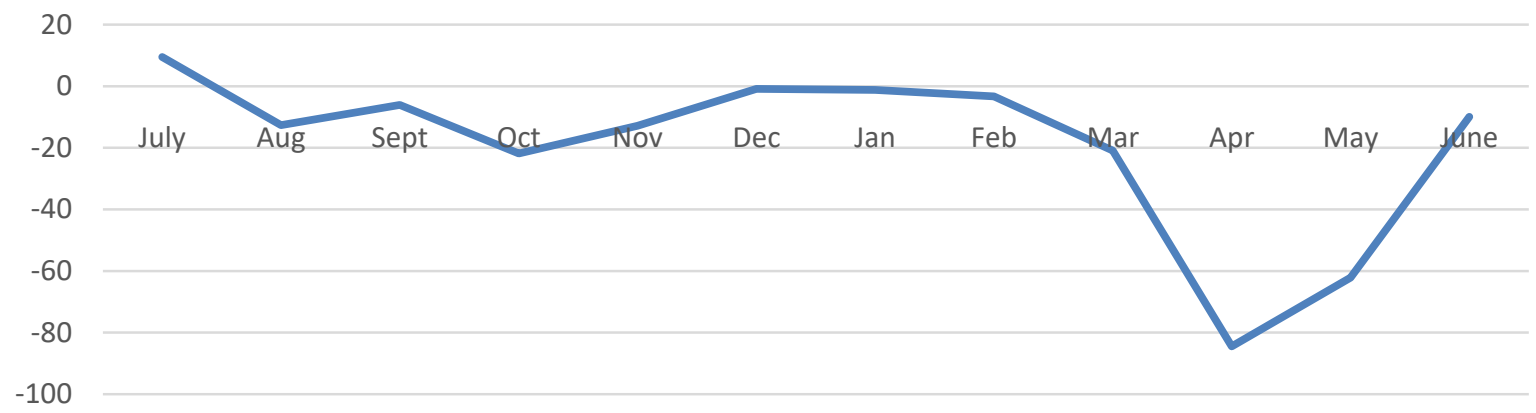

Figure 9. Total Export rate of Knit Product. Source: Author compilation from EPB, Bangladesh. 


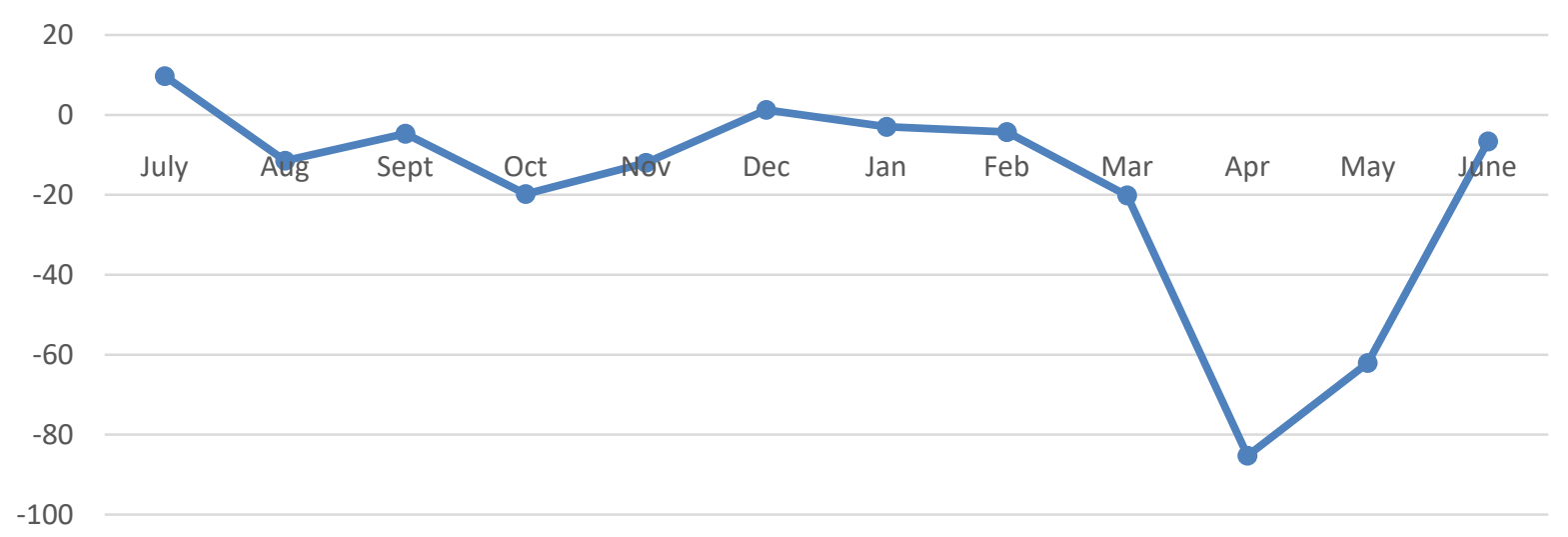

Figure 10. Total Export (Woven and Knit). Source: Author compilation from EPB, Bangladesh.

\subsection{Vulnerable Workforce}

According to Bangladesh Bureau of Statistic, 85.1\% of Bangladeshi workforces are engaged in informal sector (Figure 11). Now they are struggling to cope with this situation.

\section{Vulnarable Workforce in Different Sectors in Bangladesh}

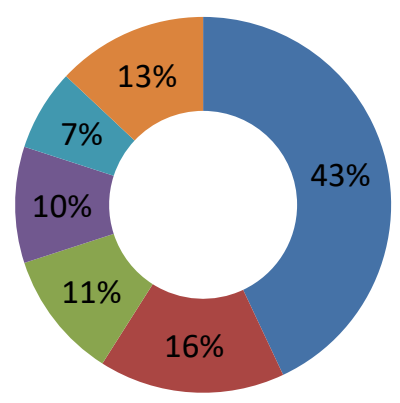

Agriculture, Livestock \& Fishing

- Ready Mate Garments

Retail Business

- Transportation

Construction

Others

Figure 11. Vulnerable Workforce in Different Sectors. Source: South Asian Network on economic modeling.

The RMG segment is on edge of uncommon humanitarian and business disaster. According to an overview directed by the BRAC University, 47\% RMG laborers are not getting their wages defying government lockdown (Figure 12).

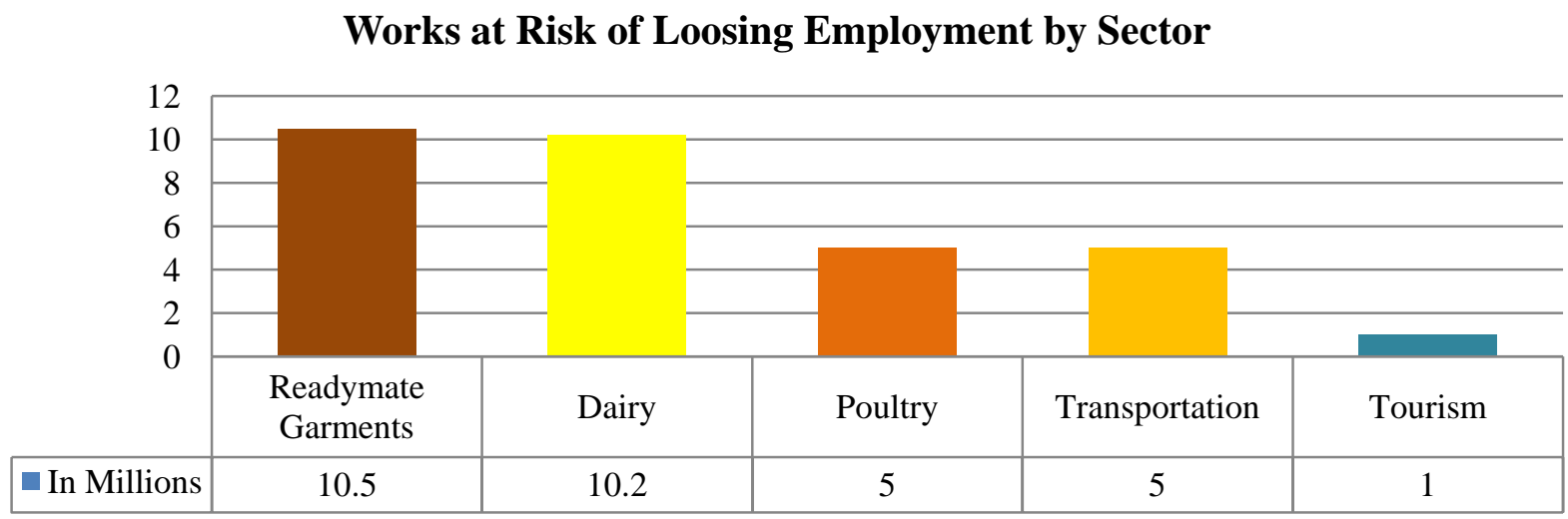

Figure 12. Workers at risk of losing employment by sector. Source: The Daily Star. 


\subsection{SME Sector}

With RMG business backward-linkage industries developed a \$6 billion industry; there are 1,461 assembling units of which 425 are in yarn fabricating, 796 in texture creation and 240 in coloring printing-completing tasks. Besides, there are enormous number of accessories suppliers for buttons, zippers, threads etc. Most of them are small medium entrepreneurs. SME sector created employment of 7.8 million people directly and provided livelihood of 31.2 million people. A study shows $69 \%$ of SMEs will not survive a lockdown more than 120 days (Figure 13).

\section{Servival Capacity of SME Sector in Lockdown}

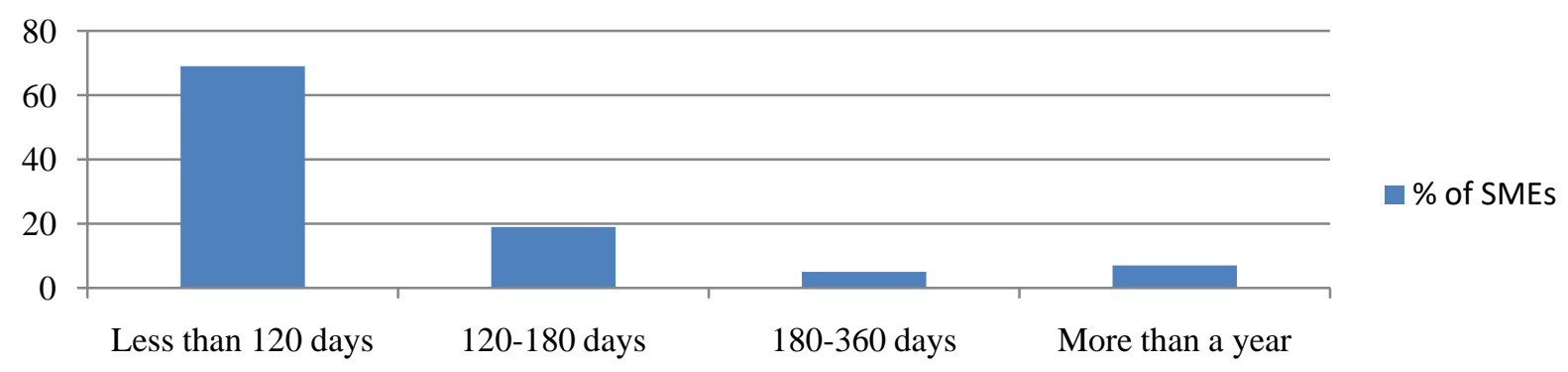

Figure 13. Survival Capacity of SME Sector in Lockdown. Source: Light castle Analytics Wing.

\subsection{Banking Sector}

59 banks and 46 and insurance company heavily relies on RMG and its backward linkage industries. Due to mounting non performing loans banking sector was in back gear at present days. As per central bank total amount of default loan stood BDT 116,288 crore in September, 2019. Figure 14 states about COVID-19 impact on credit and deposit in Banking Sector.

\section{Credit \& Deposit in Banking Sector}

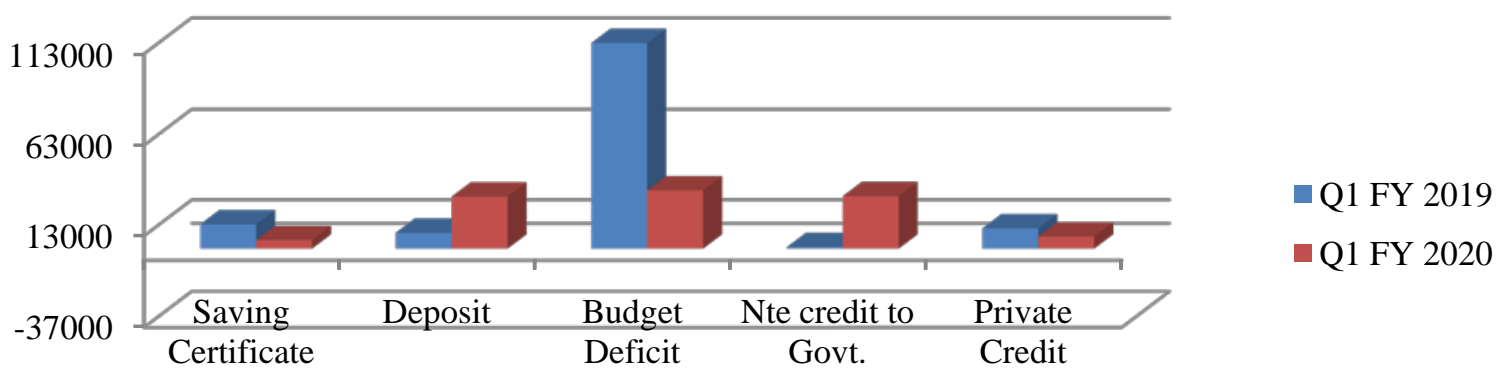

Figure 14. COVID-19 impact on credit and deposit in banking Sector. Source: The Daily Star.

\section{Findings and Discussion}

It may seem that we are facing an economic slowdown in the short term, but the real scenario is for the long term there will be a recession. Due to pandemic developed countries are facing medium to long term recession and due to plummeting of oil price there is an enormous economic pressure on oil producing countries economy. These all are a major setback in remittance inflow, export earning, industrial production and other services sectors. IMF and World Bank projected real GDP of Bangladesh is to decelerate to 2\% in FY 2019-20. The damage on the Bangladesh economy will actually depend on the pervasiveness and duration of COVID-19 as well as the effectiveness of government measures. As per Bangladesh Bureau of Statistics around 34 million people of Bangladesh live below poverty line. This outbreak may raise the amount to thirty six million and their family earnings may fall up to $25 \%$. The impact is observed in three main avenues: First domestic economic activity plunged after the shutdown; second is the declination of readymade garments exports which fell by 83\%; third is the fall down in remittance. The country's 
economy came at standstill state and debilitating effects observed in every sector.

\subsection{Government Initiative}

To mitigate the losses in RMG sector Government of Bangladesh has declared an incentive package of BDT 5,000 crore. Later on April 05, 2020, another stimulus package of BDT 72,750 was unveiled by government to address the economic impact of COVID-19 outbreak. The government also planned a bailout plan which include stimulate package for different economic sector, widening the coverage of social safety net programs, distributing foods to poor people at a lower price, increasing monetary supply and so on. Bangladesh Bank also has taken so many healthy initiatives which includes but not limited to reduction in repo interest rate, 50 billion refinance scheme for agriculture sector, buy back of government securities, 30 million refinance schemes for low income professional, relaxation of advanced deposit ratio, and so on.

\subsection{Challenges}

For a densely populated country like Bangladesh, it is a huge challenge to contain the impact of contagious disease like COVID-19. It is evident that we have limited health infrastructure. We need around 250 million USD only for clinical equipment testing and contact tracing. There is no denying fact that business-political nexus is involved with money laundering. A recent report says that the amount of cash flight per year from Bangladesh is around 7.53 Billion US dollar. With all these keeping budget deficit within 5 percent of GDP and ensuring social spending at the same time may be a challenge.

\section{Recommendations and Conclusion}

It is observed that in Bangladesh, rich people are much more benefited than poor people by higher growth rate and increased per capita income. This crucial issue should be addressed to chalk out a long-term plan to minimize disparity.

Bangladesh was unable to diversify export basket which created a risk in export portfolio. The excessive reliance on the RMG sector resulted export contraction. We have to diversify our basket and reduce sole dependency on RMG industry. Beside this RMG sector should wider the higher value goods of different variety and explore new markets.

Banking sector is considered as the key player of the economic activities. Due to non-performing loan, we were suffering before the outbreak. The COVID-19 outbreak made the case worse. Therefore, new sets of guidelines needed to be initiated by Bangladesh Bank. It is essential to focus on the early bailout plan for probable collapse of large loan. Beside that every bank and financial institution need to assess and reassess their lending portfolio and withdraw unnecessary portion. To make this happen state owned bank should be reformed, capital of the banking sector should be increased and legal and regulatory requirements should be enforced.

At present, we have a weak revenue collection system. We really need to emphasize on the revenue collection and discourage subsidies in various non priority items like liquefied gas imports. To buffer the economy against the external shocks increased exchange rate should be carried on by Bangladesh Bank. The government also needs to focus on foreign direct investment. For that business environment should be improved.

For effective and proactive microeconomic management, government should keep track of monthly economic development. Since $60 \%$ of the informal workers are employed in the non-formal sector, government should make some policies for them. For this support should be extended to small business, livelihood should be preserved through employment retention and public work program should be established.

Government should consider an unconditional cash transfer program at a rate of 95 USD or 8,000 BDT which corresponds to minimum wage for formal sector in Bangladesh. This program can be carried out for three months.

Government will have to implement all precautionary measures adopted strictly to control the outbreak. The health system should be strengthened and poor affected people and returnee migrant worker should be provided with medical support.

We have to decrease our dependency to buy raw materials from china and explore different market to have alternatives. We have to make an import priority list so that non essential items can be imported later.

For the corona affected workers a job support scheme should be initiated by the government. A special financial scheme for the small enterprises should be initiated so they can have a working capital.

In RMG sector, Bangladesh has to compete with both Myanmar and Vietnam. So Bangladesh needs to keep track of the things around the world so that we can formulate the best strategy in the RMG industry. We have 7 crore mobile internet subscribers which platform may be used to shift to e marketing. 
Finally, all the measures and effort took by government should be strictly administrated and monitored to ensure transparency so that willful loan defaulters and fake victims do not take the advantage.

\section{References}

Bangladesh Garments Manufacturer Exporters Association. (2020). Impact of COVID-19 on Bangladesh RMG Industry, accessed July 10, 2020 at 01:28 am <https://www.bgmea.com.bd/home/pages/TradeInformation>.

Corona info 2020 Update of Coronavirus in Bangladesh, Accessed 14 July 2020 at 00:30 pm https://corona.gov.bd/?gclid=Cj0KCQjwoub3BRC6ARIsABGhnybVPK89HGTDt3n6cA4HpbA5GNA1PL6mI-xbg iKDLvu9fEdoYtonVT8aAsj0EALw_wcB.

Global Times. (2020). Economic ramifications of Covid-19 in Bangladesh. 11 May 2020.

International Monetary Fund. (2020). Helping Bangladesh Recover from COVID-19, accessed July 1, 2020 at 01:28 am https://www.imf.org/en/News/Articles/2020/06/11/na-06122020-helping-bangladesh-recover-from-covid-19.

Khatun, F. (2020). COVID-19 batters Bangladesh's already struggling economy. Accessed 03July 2020 at 04:07am $<$ https://www.eastasiaforum.org/2020/05/07/covid-19-batters-bangladeshs-already-struggling-economy/> .

Light castle Analytics Wing. (2020). COVID-19 Impact on the SME Sector of Bangladesh, accessed July 1, 2020 at 12:01 am https://www.lightcastlebd.com/insights/2020/05/09/ covid-19-impact-on-the-sme-sector-of-bangladesh.

Murphy, M. (2017). The Economization of life. Durham: Duke University Press.

New Age. (2020). Corona virus pandemic and leaving no one behind. 13 April.

Saleh, A. (2020). In Bangladesh, COVID-19 threatens to cause a humanitarian crisis. World Economic Forum, accessed 03 July 2020 at 02:52 am, <https://www.weforum.org/agenda/2020/04/in-bangladesh-covid-19-could -cause-a-humanitarian-crisis/>.

The Asian Development Bank (ADB). (2020). COVID-19 Outbreak to Have Significant Economic Impact on Developing Asia. Accessed 27 June 2020 at 8:07 am https://www.adb.org/news/covid-19-outbreak-have-significant -economic-impact-developing-asia.

The Business Standard. (2020). Covid-19 and its impact on Bangladesh economy, 15 April 2020.

The Daily Ittefaq. (2020). How Bangladesh's leaders should respond to the economic threats of COVID-19. 11 April 2020.

The Daily Star. (2020a). COVID-19 and the economisation of life in Bangladesh, 10 May.

The Daily Star. (2020b). Brac Rapid Survey: 47pc garment workers yet to be paid. 19 April.

World Bank. (2020). Bangladesh Must Ramp Up COVID-19 Action to Protect its People, Revive Economy. Accessed 03 July 2020 at 03:34 am <https://www.worldbank.org/en/news/press-release/2020/04/12/bangladesh-mustact-now-to-lessen-covid-19-health-impacts> .

Worldometers. (2020). Reported Cases and deaths by Country, Territory, or Conveyance. Accessed 12 July 2020 at 02:09 am. <https://www.worldometers.info/coronavirus/?utm_campaign=homeAdUOA?Si\%3Ca\%20href=>. 